\title{
Reciprocal Learning Strategy in CALL Environment: A Case Study of EFL Teaching at X University in Shanghai
}

\author{
An Liu ${ }^{1,2}$, Yuhua Bu, ${ }^{1, *}$ \\ ${ }^{1}$ Department of Education Science, East China Normal University, China \\ ${ }^{2}$ Department of College English, Tong Ji University, China
}

Copyright $\mathrm{O} 2016$ by authors, all rights reserved. Authors agree that this article remains permanently open access under the terms of the Creative Commons Attribution License 4.0 International License

\begin{abstract}
Colleges and universities in China have been bent on remolding the existing unitary teacher-centered education mode and enhancing students' individualized and autonomous learning with the help of multimedia and cyber technology in order to meet the College English Curriculum Requirements instituted by the Ministry of Education in 2004. Admittedly Computer Assisted Language Learning (CALL) has shed some light on the enhancement of individualized and autonomous learning. Yet a lot more work needs to be done to make it truly efficient and effective. This paper, taking X University in Shanghai as an example, investigates how reciprocal learning can be integrated into the design and delivery of various activities in EFL (English as a Foreign Language) teaching and explores how EFL teachers can formalize, encourage and make explicit reciprocal learning. With consideration of such practical issues as assessment and planning, it may be valuable in optimizing EFL teaching in the E-learning environment.
\end{abstract}

Keywords Reciprocal Learning Strategy, CALL, EFL Teaching

\section{Introduction}

Ever since the 1990s the advent of digital technology as well as the information technology and cyber technology has exerted great influence on virtually all levels and aspects of education, including language learning. Computer-assisted Language Learning (CALL), defined by Levy [1] in his seminal work as "the search for and study of applications of the computer in language teaching and learning", embraces a wide range of information and communications technology applications and approaches to language teaching and learning. Currently, the philosophy of CALL attaches great importance to student-centered materials that allow learners to work on their own. Those materials, structured or unstructured, usually characterize interactive learning and individualized learning, which coincide with the goals of the ongoing college English education reform in China where institutions of higher learning are urged to make full use of multimedia and cyber technology to reform the traditional monotonous teacher-centered classroom teaching mode by establishing students' dominant role in the teaching process and to orient college EFL teaching to the needs of autonomous learning.

True, CALL as a useful tool has helped teachers to facilitate the language learning process and learners to reinforce what has been learned in the classroom, but relevant studies have shown that the vast potentials of the computer have not yet fully been utilized in China's classrooms. The doctoral dissertation written by Chen [2] shows that presently in China CALL has not essentially transformed the traditional teacher-centered teaching mode in college English education. The old-fashioned mode of "blackboard + chalk" has only slightly been converted into that of "computer + blackboard + chalk". In this regard, a lot more work needs to be done to make CALL truly efficient and effective. The work by Huang [3] analyses courses and teaching models of some universities and finds that teachers themselves play a very important role in English language teaching reform which will not be geared towards students' individualized and autonomous learning unless they improve their teaching concepts and consciously integrate computer into teaching programs. Yuan [4] discusses related researches on reciprocal teaching in the last two decades and considers it a form of teaching reading comprehension strategy which integrates the characteristics of expert modeling and teaching in groups.

The present paper reviews the status quo of EFL teaching in X University and studies how reciprocal learning can be integrated into various activities in college English education in order to optimize students' autonomous learning in the electronic learning environment. With consideration of issues such as assessment and planning, it explores how teachers can formalize, encourage and make explicit reciprocal learning in their teaching process. 


\section{The Concept of Reciprocal Learning}

The process of teaching is one that involves mutual interaction and joint development between instructors and learners. There could be a failure in teaching or learning with the absence of interactive communication between teachers and students. On the other side of the coin, positive interaction between students themselves is also essential inside and outside the classroom, especially against the current backdrop of cultivating individualized and autonomous learning in college English education. Thus it pays to establish a liberal yet harmonious student-student relationship on equal terms so as to build new learning communities to better meet the requirements of education reform here in China.

According to Manabu Sato [5], education professor of the University of Tokyo in Japan, in the $21^{\text {st }}$ century people from diversified backgrounds respect each other's differences and coexist in the society. They seek to learn from each other by modestly listening to others while providing their own insights without reservation. From Sato's perspective, learning is a reciprocal process in which experience, knowledge and wisdom is shared between instructors and learners as well as between learners themselves.

In the context of school education, reciprocal learning is an instructional model in which students work in pairs or groups to master the lesson content. According to Mosston [6], students involved in reciprocal learning cooperate in well-defined roles of doer and observer (i.e., tutor and tutee) to maximize their own and each other's learning. While one learner is doing (doer), the other learner (observer) is observing, analyzing the doer's performance, and giving performance-related feedback. In the eyes of Baxter Magolda [7], reciprocal learning also improves meta-cognition which is the process of reflecting on the building of knowledge. Through this strategy, students explain their learning to other students and essentially take turns being the teacher with the teacher acting as a facilitator to assist the student-teacher in clarifying their ideas and activities. This process forces students to put their ideas into words, which aids organization and retention.

There are subtle differences between reciprocal learning and other social instruction strategies such as active learning, collaborative learning, and autonomous learning.

In the case of reciprocal learning strategy, the emphasis is on collaborative rather than independent learning. Students are taught to help one another. In this strategy, students work together as peer partners, each functioning in turn as the "doer" and the "guide" in completing the task. Peer feedback doesn't mean students "grade" each other or score papers. Instead the goal is for students to clarify for each other what is correct or incorrect.

Active learning, according to Brown [8], is dominated by students' meta-cognitive awareness of the purposes and goals of the instruction. It is strategic, self-conscious, self-motivated, and purposeful.

Collaborative learning, argues Mitnik [9], is based on the model that knowledge can be created within a population where members actively interact by sharing experiences and take on asymmetry roles. Simply put, it refers to methodologies and environments in which learners engage in a common task where each individual depends on and is accountable to each other.

As to autonomous learning, learners are viewed as individuals who can and should be autonomous i.e. be responsible for their own learning climate. Autonomous learners usually get to decide what projects they wish to tackle or what interests to pursue and develop such attributes as self-consciousness, vision, practicality and freedom of discussion which serve to aid them in independent learning.

For all the differences between the above social instruction strategies, they are not mutually exclusive or incompatible in actual teaching or learning processes. Instead, a flexible combination of one or two or more strategies is invariably found in classroom instructions. Yet given the limited space available here, we will not delve into the details of these strategies and will only focus on reciprocal learning together with its possible application to the college English teaching process so as to improve students' individualized and autonomous learning in the computer-assisted learning environment.

\section{The Status Quo of EFL Teaching in X University}

The arrival of digital technology, information technology as well as cyber technology has provided an important foundation and offered broad prospects for enhancing EFL teaching in China's universities. In view of the changes in time, the College English Curriculum Requirements issued in 2004 by the Education Ministry of China urges the establishment of a brand-new teaching mode labeled as "the Computer-and -Classroom-based College English Teaching Model", which is illustrated below: 
Table 1. Computer-and-Classroom-Based Teaching Model

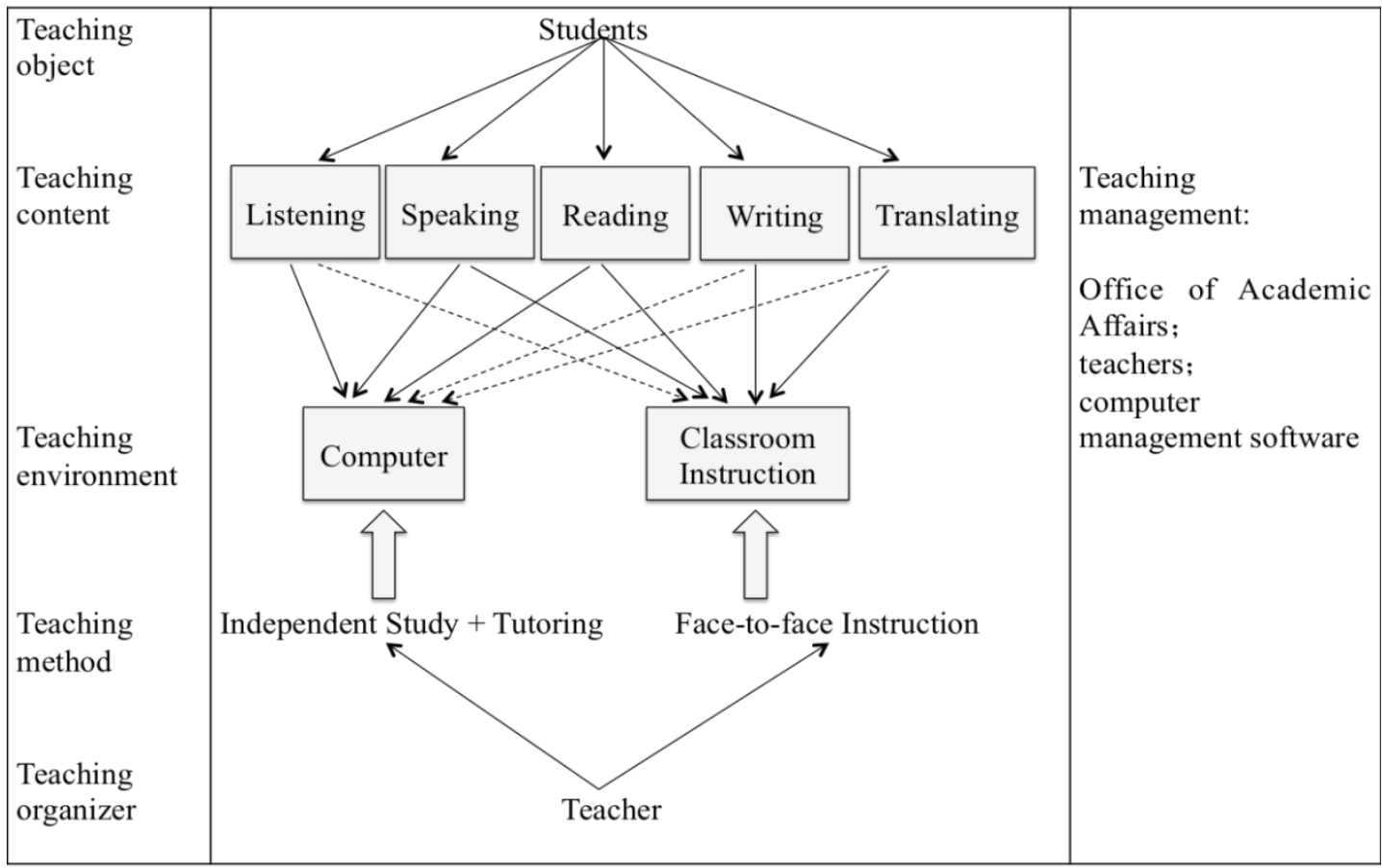

The new teaching model in Table 1 encourages the utilization of modern information technology, allowing EFL teaching and learning to take place without constraints of time or space. Obviously, different from the traditional teaching model (in Table 2) in which all five essential skills associated with English proficiency, namely "listening", "speaking", "reading", "writing" and "translating", are cultivated in the classroom, in the new teaching model, "listening" is mainly practiced after class in the CALL environment with minor auxiliary instruction in class; "speaking" and "reading" practices are to take place both during classroom instruction and in the E-learning environment; "writing" and "translating", however, are mainly done in class, supplemented by online exercises with the assistance of computer.

Table 2. Traditional Teaching Model

\begin{tabular}{|l|l|l|l|}
$\begin{array}{l}\text { Teaching } \\
\text { object } \\
\text { content }\end{array}$ \\
$\begin{array}{l}\text { Teaching } \\
\text { environment }\end{array}$ \\
$\begin{array}{l}\text { Teaching } \\
\text { method }\end{array}$ \\
$\begin{array}{l}\text { Teaching } \\
\text { organizer }\end{array}$
\end{tabular}


Admittedly, it has been nearly a decade since the promulgation of the College English Curriculum Requirements. So what is the status quo of the implementation of the "Requirements" and the actual ongoing teaching model adopted in China's universities? Let's take X University as an example.

$X$ University, a 100-odd-year-old university located in Shanghai, China, covers ten categories of academic disciplines, including engineering, science, medicine, management, economics, philosophy, literature, law, education and arts. It registers more than 18000 full-time undergraduate students, most of whom (except English majors) are offered 4 semesters of EFL courses during their first freshmen and sophomore years. An overview of the EFL curriculum and teaching model at X University is illustrated as follows:

Table 3. The First Year EFL Curriculum

\begin{tabular}{|c|c|c|c|}
\hline 1 st Year & Class & Target students & Textbooks \\
\hline \multirow{5}{*}{$1^{\text {st }}$ Semester } & College English Al & $\begin{array}{l}\text { Below average students based on the college entrance } \\
\text { examination (CEE) achievement }\end{array}$ & New College English (second edition) (Integrated Course)Book 1 \\
\hline & Special English 1 & $\begin{array}{l}\text { Students with outstanding athletic achievement and } \\
\text { students majoring in Performing Arts }\end{array}$ & New Concept English Book 2 \\
\hline & College English Band 3 & Average students based on the CEE achievement & $\begin{array}{l}\text { New College English (second edition)（Integrated Course ) Book 3; } \\
\text { New College English (first edition) (Reading Course ) Book 2; } \\
\text { New standard college English（Listening\& Speaking）Book 2; }\end{array}$ \\
\hline & College English Band 4 & $\begin{array}{l}\text { Students majoring in Chemistry, Civil Engineering, } \\
\text { Mechanics }\end{array}$ & $\begin{array}{l}\text { New College English (second edition)（Integrated Course ） Book 4; } \\
\text { New standard college English（Listening\& Speaking） Book 3; } \\
\text { And as appropriate }\end{array}$ \\
\hline & Comprehensive English 1 & $\begin{array}{l}\text { Top Students with outstanding achievement in the CEE } \\
\text { English Test }\end{array}$ & As appropriate (similar to textbooks used in selective courses for sophomores) \\
\hline \multirow{5}{*}{$\begin{array}{l}2^{\text {nd }} \\
\text { Semester }\end{array}$} & Special English 2 & Those who have completed Special English 1 & New Concept English Book 2 \\
\hline & College English Band 4 & Those who have completed College English Band 3 & $\begin{array}{l}\text { New College English (second edition)（Integrated Course）Book 4; } \\
\text { New College English (first edition) (Reading Course ) Book 3; } \\
\text { New standard college English（Listening\& Speaking）Book 3; }\end{array}$ \\
\hline & College English Band 5 & Those who have completed College English Band 4 & $\begin{array}{l}\text { New College English (second edition)（Integrated Course）Book 5; } \\
\text { New College English (first edition) (Reading Course ) Book 4; } \\
\text { New standard college English (Listening\& Speaking) Book 4; }\end{array}$ \\
\hline & College English Band 5 & $\begin{array}{l}\text { Students majoring in Chemistry, Civil Engineering, } \\
\text { Mechanics who have completed College English Band } \\
4\end{array}$ & $\begin{array}{l}\text { New College English (second edition)（Integrated Course）Book 5; } \\
\text { New standard college English（Listening\& Speaking）Book 4; } \\
\text { And as appropriate }\end{array}$ \\
\hline & Comprehensive English 2 & Those who have completed Comprehensive English 1 & As appropriate (similar to textbooks used in selective courses for sophomores) \\
\hline
\end{tabular}

Table 4. The Second Year EFL Curriculum

\begin{tabular}{|c|c|c|c|}
\hline 2nd Year & Class & Target students & Textbooks \\
\hline \multirow{4}{*}{$\begin{array}{l}3^{\text {rd }} \\
\text { Semester }\end{array}$} & College English A3 & Those who have completed College English A2 & New College English (second edition) (Integrated Course)Book 3 \\
\hline & Special English 3 & Those who have completed Special English 2 & New Concept English Book 3 \\
\hline & Selective Courses in English & Those who have completed College English Band $4 \& 5$ & $\begin{array}{l}\text { Varied teaching materials on journalism, interpretation and translation, } \\
\text { linguistics, practical writing, intercultural communication, Chinese culture, } \\
\text { business English, public speaking, etc. }\end{array}$ \\
\hline & $\begin{array}{l}\text { English for Academic } \\
\text { Purposes }\end{array}$ & $\begin{array}{l}\text { Students majoring in Chemistry, Civil Engineering, } \\
\text { Mechanics who have completed College English Band } \\
5\end{array}$ & Varied teaching materials on English for Academic Purposes as appropriate \\
\hline \multirow{4}{*}{$4^{\text {th }}$ Semester } & College English A4 & Those who have completed College English A3 & New College English (second edition) (Integrated Course)Book 4 \\
\hline & Special English 4 & Those who have completed Special English 3 & New Concept English Book 3 \\
\hline & Selective Courses in English & $\begin{array}{l}\text { Those who have taken a selective course the previous } \\
\text { semester are to take a different one }\end{array}$ & $\begin{array}{l}\text { Varied teaching materials on journalism, interpretation and translation, } \\
\text { linguistics, practical writing, intercultural communication, Chinese culture, } \\
\text { business English, public speaking, etc. }\end{array}$ \\
\hline & \begin{tabular}{|lll} 
English for Academic \\
Purposes
\end{tabular} & $\begin{array}{l}\text { Students majoring in Chemistry, Civil Engineering, } \\
\text { Mechanics }\end{array}$ & $\begin{array}{l}\text { More varied teaching materials on English for Academic Purposes as } \\
\text { appropriate }\end{array}$ \\
\hline
\end{tabular}


The above tables present a general picture of what is going on in regard to the content of EFL education at X University where English as a compulsory course is offered to freshmen and sophomores. It is noted that during the freshmen year varied courses in English are offered to students from diverse backgrounds and that specific teaching content is arranged flexibly according to their actual English level. At this stage, more attention is given to strengthen students' overall capabilities in English speaking, listening, reading, writing and translating. This is obviously shown from the textbooks used during the first year such as New Concept English, New College English, New standard college English, and the like, which aim at fostering English proficiency comprehensively. In the second year, on the other hand, the focus is shifted to offering EFL courses according to students' interests and /or specialties. Most students are in the position to choose a selective course in view of their own needs or interests, except for those from departments of Civil Engineering, Mechanics and Chemistry which have individualized requirements for EFL teaching. It is noted that the five skills associated with English proficiency may not be cultivated comprehensively in the classroom. Courses like Learning English through Viewing, Listening and Speaking focuses more on listening and speaking skills; whereas Selected Readings in English Newspapers and Magazines lays more emphasis on reading, writing and/or translating skills. As a result, the EFL teaching modes in the first two years are also somewhat different, as are illustrated below:

Table 5. The Current EFL Teaching Modes at X University

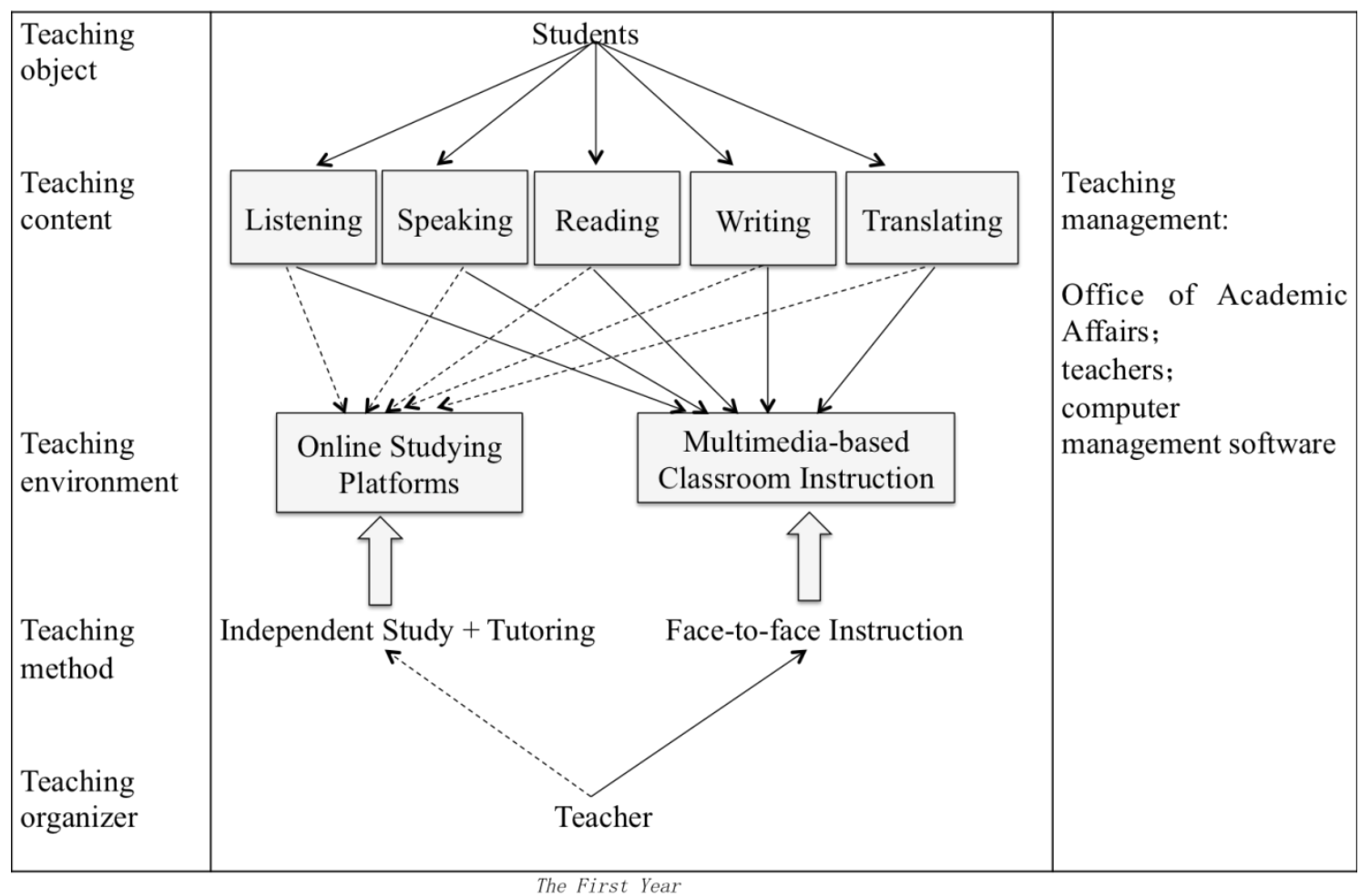




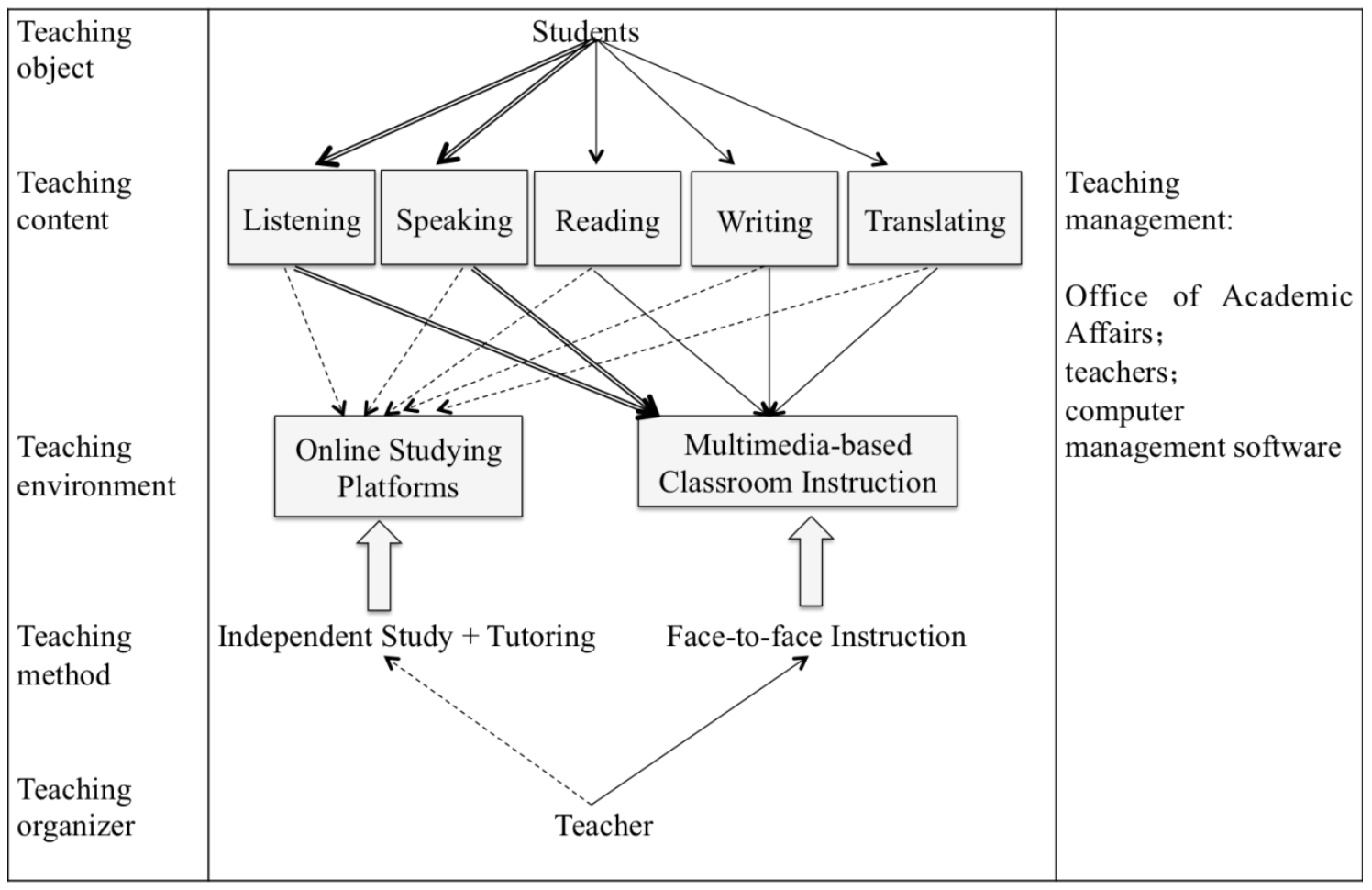

The Second Year

Even though the EFL teaching modes at X University more or less conform to "the Computer-and -Classroom-based College English Teaching Model" designated by the Education Ministry, there are a number of disparities in that the five essential skills are still practiced mainly in class, only supplemented by online exercises both lack of efficiency and in want of supervision. It is also noteworthy that unitary multimedia teaching mode is adopted in class regardless of the differences in textbooks, courses, and students themselves. As a member of the EFL teaching faculty at X University, the author has noticed that computer is but one of the teaching aids, similar to blackboard or whiteboard in the traditional classroom. In addition, it deserves attention like most colleges and universities in China. $X$ University has set up a few Web-based teaching platforms for students' autonomous study after class. Yet in reality, CALL is limitedly implemented during class instruction only; students' independent study or teachers' tutoring in the electronic learning environment is not sufficiently monitored after class. True, an amount of pair work or group work among students is indeed conducted in class or after class, but it is far from what is called collaborative or reciprocal learning, let alone autonomous learning, in that team work is organized slackly and inefficiently, probably due to the lack of incentive mechanism or specific team-work-based evaluation system.

Then, what about other universities that have established Web-based teaching platforms for autonomous study? According to the survey conducted in Dong Nan University and Shanghai University of Engineering Sciences by Chen [10], although above $90 \%$ of the students surveyed welcome
CALL, only $10 \%$ of the students find that their ability in autonomous learning has significantly been promoted with the help of the Web-based teaching platform. More than half of the students feel that they haven't gained much in the E-learning environment due to frequent equipment failure or lack of interest in the teaching resources online which are identical to the textbook itself.

Evidently the status quo of EFL teaching in China's university classroom has not fully lived up to the expectations of college English education reform. Nor is it entirely compatible with the "Computer-and Classroom-based College English Teaching Model" designated almost a decade ago. There is yet a long way to go before computer truly becomes an integral part of EFL education to effectively foster individualized and autonomous learning.

\section{Integration of Reciprocal Learning Strategy into College English Education}

In view of the existing problems and difficulties in college English education in China, we attempt to introduce reciprocal learning strategy into the "Computer-and Classroom-based College English Teaching Model" to see what language teachers can specifically do to help optimize students' autonomous learning in the CALL environment. It is noted that learners don't study or work alone in this respect. They break up into learning communities where they look out for each other and establish reciprocal relationships. Also 
they are motivated to work together towards common goals in class as well as on virtual learning platforms under the supervision of the teacher.

\subsection{Establishing Autonomous Learning Platform}

To be frank, it is undoubtedly hard for students to achieve autonomous learning in the electronic environment without a well-maintained online teaching and learning platform. For institutions that do not have such facilities, it is necessary to set up such a platform in the first place. For others like X University that have already provided similar facilities, it is important to upgrade the hardware and software to optimize the individualized and autonomous learning environment when students are obviously not satisfied with what is provided on the platform where the teaching and learning resources available are similar to paperback textbooks or reference books in terms of content. At X University, there are currently three online learning platforms, namely "College English Learning Management", "New Perspective Foreign Language Teaching and Learning Platform", and "College English Applied Courses Platform". The first two, maintained by the two publishers of textbooks used by freshmen at X University, provide supplementary learning materials related to the textbooks. The third, purchased from Beijing Foreign Studies University, offers online video courses such as Survey of British and American Culture and Society, Business English, Practical English Writing, Movie English, etc. to sophomores. These three platforms provide ready-made resources for students to choose from, which is also a great defect in that they cannot be renewed or updated.
Fortunately, there are a number of universities in China that have done well in this regard. Shanghai International Studies University (SISU) is a good case in point. The work of $\mathrm{Yu}$ [11] shows that $98 \%$ of the students surveyed are satisfied with the autonomous learning environment there and $95 \%$ of them find it convenient and efficient. The overall framework of the autonomous platform in SISU is illustrated in table 6.

Table 6 indicates that extensive learning resources are open to students to optimize their individualized and autonomous learning. In SISU, such hardware facilities as campus network, satellite TV receiving system, multimedia classroom, as well as digital language laboratory have been set up to meet the increasing demands of the faculty and students. They are quickly linked to SISU library, Shanghai Library, overseas libraries, as well as a variety of digital libraries at home and abroad. As to the virtual learning resources available online, language learners in SISU have easy access to a variety of audio and visual materials including lecture videos of renowned professors, imported movies in English, Spanish, Korean, French, Japanese, and other minor foreign languages, electronic copies of classics or bestsellers of world literature, as well as listening materials such as TOEFL, IELTS, VOA, BBC, etc.

Admittedly, setting up an ideal E-learning environment alone is not enough. It is also necessary to monitor students' individual learning process online and to facilitate their virtual communication activities so as to enhance reciprocal learning, which will be dealt with in the following sections of this paper.

Table 6. A framework of autonomous platform

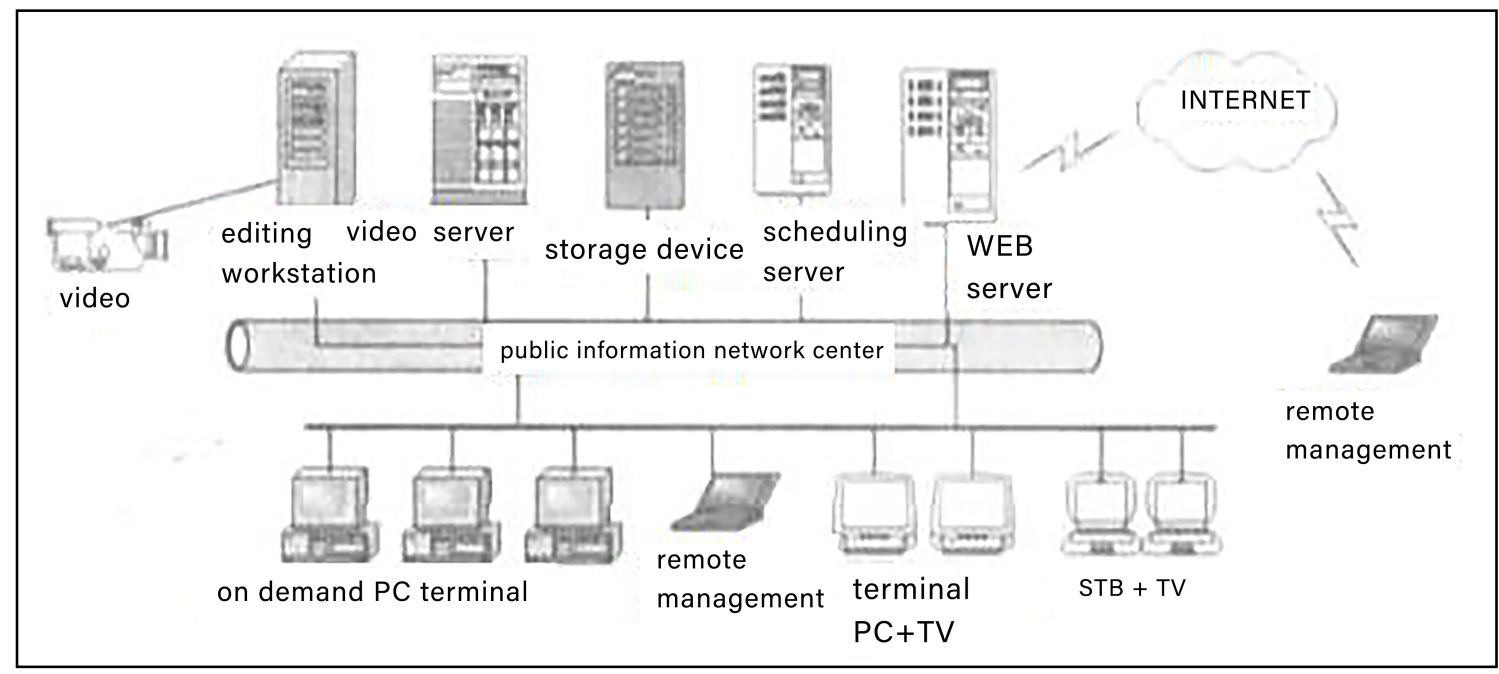




\subsection{Organizing Learning Communities}

A learning community is a group of people who share common emotions, values or beliefs actively engaged in learning from each other. According to community psychologists McMillan and Chavis [12], there are four key factors that define a sense of community: membership, influence, fulfillment of individual needs, and shared events and emotional connections. In other words, the participants in a learning community must have a sense of belonging to the group. Also the things participants do must affect what happens in the community. Besides, a learning community must give participants a chance to meet particular needs by expressing personal opinions, or sharing stories with particular emotional experiences.

In the context of EFL education, efficient learning communities are built when 4-6 participants of different sexes, English levels, and personalities are grouped together reasonably rather than randomly. Just as a Chinese saying goes, "Workload is alleviated when a well-balanced team of men and women work together." Judging from the authors' personal experience of grouping students in class, successful teams are usually formed when an even number of boys and girls are put together and when average students are mixed with top or below average students. Also it is desirable to include one or two extrovert students in each team.

It deserves mentioning that such learning communities are not fixed throughout students' university life. They are instead expected to be regrouped each semester to form new teams and learn from as many peers as possible. They are also expected to take turns to assume particular roles within a group, such as presider, secretary, reporter, liaison or examiner in order to avoid foul cooperation.

Again, the job of optimizing students' autonomous learning doesn't stop here when reciprocal learning communities are established. Proper tasks are needed to promote effective student-student interactive communication and students' autonomous learning in class as well as after class.

\subsection{Planning Appropriate Tasks}

As previously mentioned, in the reciprocal learning strategy, emphasis is put on collaborative rather than independent learning. It can be said that collaboration is an indispensable part of language learning process. Yet not everything is suitable for encouraging collaboration within a learning community. In this regard, teachers are expected to plan lessons carefully and design proper collaborative tasks based on the teaching content and individual needs of students. In general, such tasks may range from problem-based discussions, topic-based seminars, debates, public speeches, to field-work, case studies, investigations, or group research projects.

Take the preparation of the text "The Freedom Givers" in New College English Integrated Course (Book 3), a textbook used at $\mathrm{X}$ University, as an example. Each group is asked to work on one of the following tasks: (1) to research references in the library or on the Internet concerning Martin Luther King, leader of the American civil rights movement, and to give a PowerPoint-supported presentation in class on Martin's achievement in changing the attitudes of white Americans; (2) to research the history of non-violence resistance in the library or on the Internet and prepare for a mock debate in class on the topic of "Violence or Non-violence, that is the question"; (3) to write and print out a play based on the stories of Underground Railroad heroes in the text and give a role-play in class; (4) to deliver a speech in class based on Pet fi Sándor's poem "Life is dear, love is dearer. Both can be given up for freedom" using audio-visual aids.

Supposedly each participant in a group is actively involved in the preparation process with the assistance of computer. A combination of collaborative learning and autonomous learning is encouraged during their work toward a common goal. They identify what they already know, what they need to know, and how and where to access new information that may lead to resolution of the problem. Through collaboration between participants in the same group, reciprocal learning is achieved by virtue of constructivist learning where knowledge is built from students' socially- and Web-based experience in completing such group projects.

\subsection{Guiding and Monitoring the Learning Process}

Although the focus in the E-learning environment is on students collaborating with their peers and on learning autonomously at the same time, teachers still play a vital role in facilitating learning, which is shown clearly in the survey by Chen [10], in which over $95 \%$ of the students surveyed admit that computer can never take the place of the teacher. As to what kind of help students expect to get from the teacher, more than half of them chose "fostering students' learning strategy" or "prompting students' autonomous learning and monitoring achievements in learning".

Besides, teachers who implement online learning environments also need to decide what is appropriate or inappropriate. According to Stahl [13], students who are comfortable with online communication often choose to interact casually, so teachers should pay particular attention to making students aware of their expectations for formality online. Moreover, students sometimes do not have all the skills necessary to solve problems by themselves in online communication. Teachers, in this regard, can provide what is called "scaffolding" or a platform of knowledge that learners can build on.

In brief, the role of the teacher in the electronic learning environment is to support, guide, and monitor the reciprocal learning process. The teacher must also engage in assessment in order to ensure objectives have been met for all participants in the learning community. 


\subsection{Assessing Performance Comprehensively}

Frankly speaking, desirable results will not derive from the reciprocal learning strategy unless there is a comprehensive and proper evaluation system in support of the entire learning process. Such an evaluation system might also serve as a stimulus to motivate students in the process of reciprocal learning. It looks at the performance of the learning community as a whole as well as that of the individual himself.

Teachers are not alone in the assessment process. Students are also actively involved. Comments are not only given by the teacher, participants in a learning community are also expected to offer feedback to their peers. From self-appraisal to peer review to teacher's comment, participants in the reciprocal learning community are able to discern their gradual progress and appreciate pleasure in achievements gained by the group as a whole.

In the actual EFL teaching process, such as in $\mathrm{X}$ University, language instructors usually adopt a combination of formative evaluation and summative evaluation. The former is usually a range of formal and informal assessment procedures employed by teachers during the learning process in order to modify teaching and learning activities to improve student attainment. It typically involves qualitative feedback (rather than scores) for both student and teacher that focus on the details of content and performance. Contrastively, the latter usually seeks to monitor educational outcomes, such as the final test or a term paper.

In the CALL environment, premium is often put on formative evaluation to examine learners' performance during the learning process. Progress and outcomes are generally assessed by how well individual students develop experimental and analytic skills autonomously, and by how well they work and collaborate in groups.

\section{The Effectiveness of Carrying out Reciprocal Strategies in the Classroom}

One of the authors of this paper happens to be a faculty member of X University and is able to consciously implement the reciprocal strategies in her classroom. In order to study the effectiveness of carrying out the afore-mentioned strategies, the author surveyed the 22 students in her class with a questionnaire. As the class is at the freshmen level, the current platforms they use are "College English Learning Management" and "New Perspective Foreign Language Teaching and Learning Platform". The questionnaire, put on a popular free online survey website (www.wenjuan.com) for them to complete, is composed of ten multiple-choice questions, six of which are single answer questions and four of which may contain more than one answer. The single-answer questions include:

Q1 Do you think the platforms are helpful to your English study?

Q4 Do you have a fixed partner/group for English learning?

Q5 Do you think there is a clear division of responsibilities in your group?

Q8 Do you think the group tasks/themes meaningful?

Q9 Will you ask help from your teacher?

Q10 Do you think the proportion of online platform learning is reasonable in the final grade?

The multiple-answer questions include:

Q2 What do you think are the problems of the platforms? Q3 What do you hope is to be added to the platforms?

Q6 What role do you often play in your group?

Q7 What have you learnt from group activities?

For Questions 2, 3, 6,7 students were asked to add specific information if their choice is "Others". For Questions $4,5,8,9,10$ they were asked to explain their reason for making a certain choice. The survey was conducted online with all the 22 students participating in it.

The results show that $86.27 \%$ of the students give a positive answer to Q1, considering the platforms helpful to their English study, though it is noticeable that only 1 student thinks it very helpful. The results of the other three questions (For Q2 see Table 7; For Q3 see Table 8; For Q10 see Table 9) directly related to learning platforms are illustrated below:

Table 7. What do you think are the problems of the platforms?

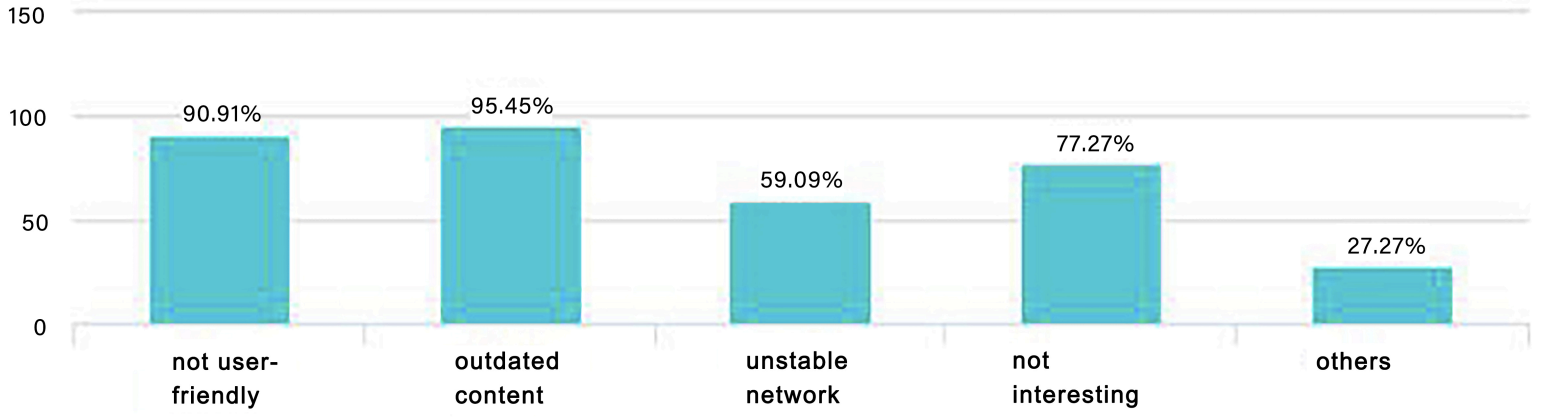


Table 8. What do you hope is to be added to the platforms?

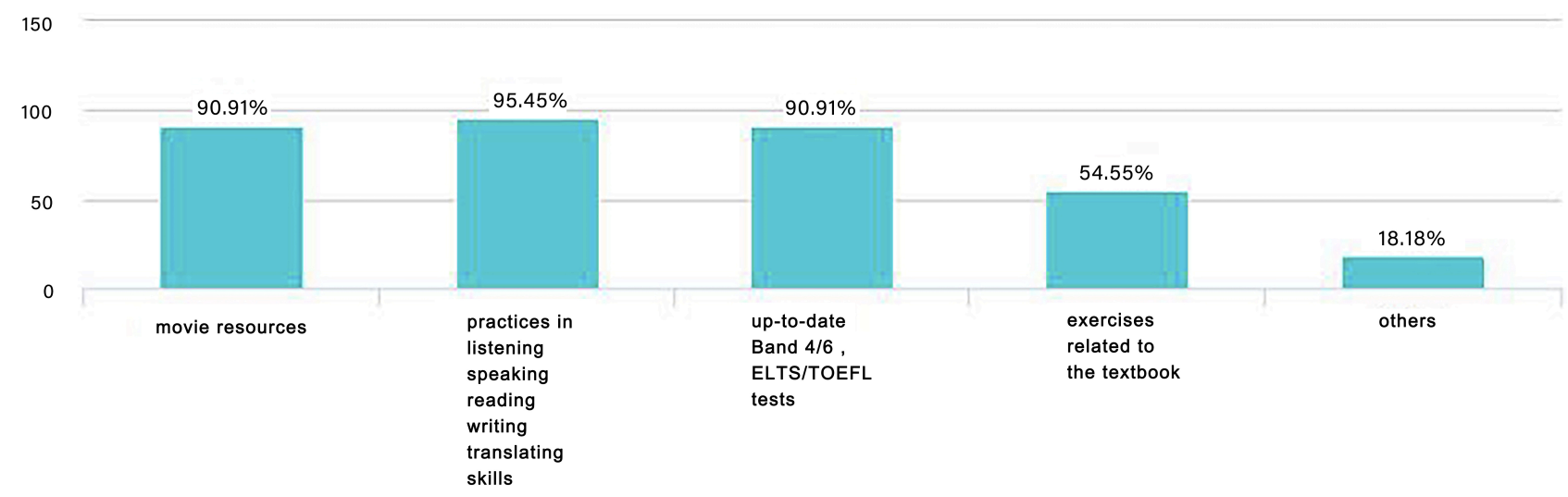

Table 9. Do you think the proportion of online platform learning is reasonable in the final grade?

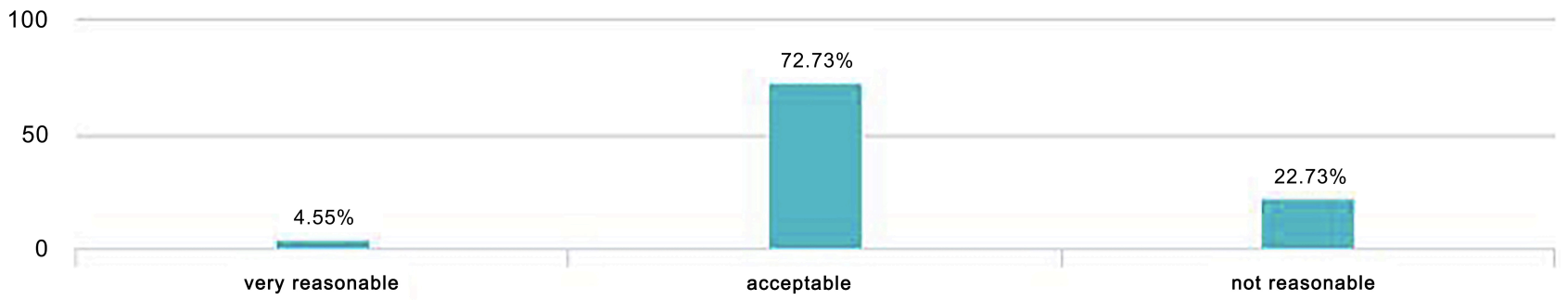

It is obvious from the above charts that a majority of students think that the platforms with their outdated content and unstable network are not user-friendly or interesting, they hope that more movie resources, practices in listening speaking reading writing translating skills, and up-to-date Band 4/6, ELTS/TOEFL tests could be added to the platforms. As to the $27 \%$ students who chose "Others" for Q2, they complained that there are too many platforms and sometimes it is too confusing for them to choose from. Other complaints include: the platforms are not suitable for interaction or it is hard to find the information they want. As to the 2 students who chose "Others" for Q3, they hope that the teacher's lesson plans and contact information could be found on the platforms. For all their complaints about the platforms, most students hold that the proportion of online learning is reasonable in their final grade (at X University, a student's final grade in EFL is usually determined by the end-term examination, completion of assignments, attendance, as well as online learning). Of the $22.7 \%$ students who think it unreasonable, they mostly complain that they have no idea how this part of grade is given. That is to say, the teacher has failed to make it clear to students how their performance in online learning is assessed. Two students complain that the platforms are not easy to use and that the record of his frequency of using the platforms was somehow cleared to zero even though he used them frequently.

As to the questions regarding the effectiveness of their group work, $73 \%$ of the students say they have a fixed partner or group for English learning. Only 18\% of the students answer "hard to say" due to the change of teachers and classmates each semester. At X University it is true that students at the beginning of each semester have to choose the teacher or the type of English class they would like to have. So it is very difficult for some of them to have fixed partners or groups to study with. As to Q6 regarding their role in the group, $18.18 \%$ are the head of their group, $13.64 \%$ work as secretary, $63.64 \%$ as speaker, $45.45 \%$ as evaluator and supervisor, and $9.09 \%$ as "Others" (he wrote "an ordinary team member" in the blank provided). From this we can see each group has a clear division of labor within them, which coincides with the results of Q5 (Do you think there is a clear division of responsibilities in your group?) where $86.36 \%$ of students ticked "Yes" to the question, with only 1 student ticked "No" and 2 chose "hard to say" because "their group head is not responsible enough".

For Q8 on their views about group activities or tasks, $68.18 \%$ of them regard them meaningful, with only $31.82 \%$ answering unmeaningful. It is more clearly illustrated in the chart below regarding their answers to Q7 about what they have learnt from group assignments (see Table 10): 
Table 10. What have you learnt from group activities?

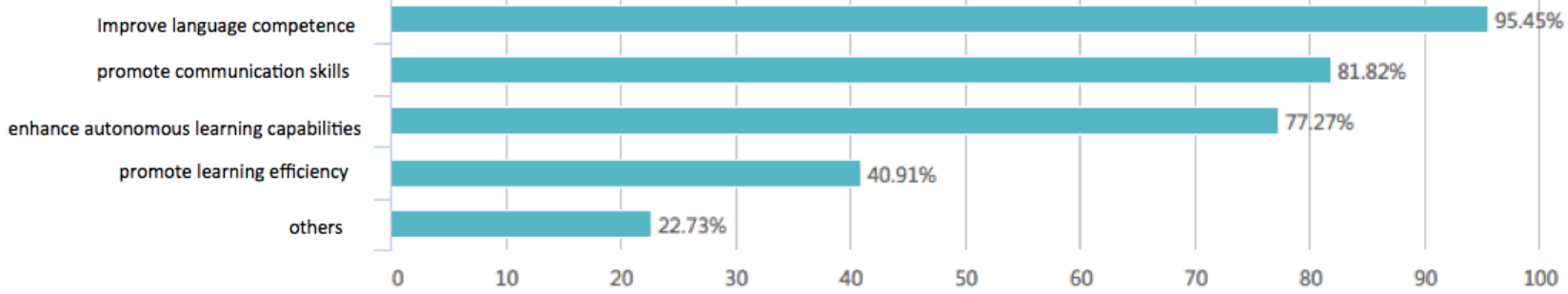

Nearly all students regard group work rewarding. From group work, they have improved their language competence, promoted their communication skills in negotiation, enhanced autonomous learning capability and promoted learning efficiency. Among the 5 students who chose "Others", 3 students hold positive attitude to group work writing that they have either promoted leading capability, or learnt how to search for references, or made friends, while the other two either say it is uninteresting or inefficient due to the fact that members come from different departments.

Question 9 (Will you ask help from your teacher?) is designed to see the role a teacher plays in students' reciprocal learning. The results (see Table 11) show that about $70 \%$ of the students will seek help from the teacher when necessary, while about $30 \%$ of students never ask help from the teacher, either because they can solve problems themselves, or because the teacher is not available after class as the teacher has no office hours. At X University not every teacher has an office. Offices are available to administrative staff, deans or distinguished professors only. Other faculty members share a meeting room which is usually used for staff meeting. In light of this, teachers usually make contact with students by email or telephone. Such factors obviously make it difficult for students and teachers to have face-to-face communication after class, undermining the effectiveness of reciprocal learning.

Table 11. Will you ask help from your teacher?

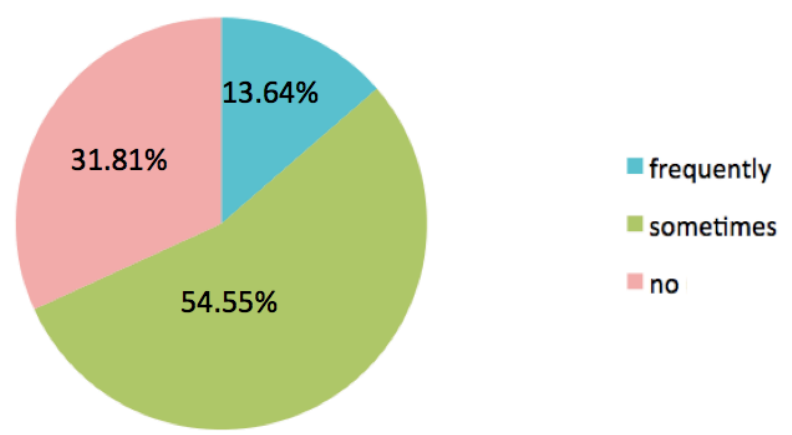

Although most students, according to the above survey, hold a positive attitude toward the reciprocal strategies implemented in their class, many problems still await corresponding solutions. Among other things, the online learning platforms need to be integrated into one and updated; the teacher needs to be more connected to students to enhance reciprocal learning; and group work needs better supervision. Admittedly, due to the limited range and scale of the survey, the above survey shows only a glimpse of what it is like after reciprocal strategies are carried out in a class. A larger-scale survey is needed to get the whole picture, which is to be carried out and discussed in depth in another paper.

\section{Summary and Conclusion}

In this paper, we have discussed how technology has shaped education historically and why CALL is not sufficiently or effectively implemented in China with respect to EFL education. We have found that there is still a long way to go before EFL teaching in China is substantially transformed from the traditional teacher-oriented teaching mode to the "computer-and classroom-based college English teaching model". We have also discussed the concept of reciprocal learning and attempted to integrate it into teaching and learning activities in college English education so as to improve students' autonomous learning in a collaborative learning community. Five factors have been considered, namely a well-maintained E-learning platform, harmonious learning communities, appropriate learning tasks, committed teachers monitoring the learning process, as well as a comprehensive evaluation mechanism. The results of a small-scale survey show that such strategies have been effective and students' language competence has to some extent been improved, but we are in want of a larger-scale survey to have a better idea about the effectiveness of such strategies which is to be investigated in a separate paper.

\section{Acknowledgements}

This work was supported by the Canadian Partnership Grants: November 2012 Competition Awards (File Number: 895-2012-1011 under the title of "Reciprocal Learning in Teacher Education and School Education between Canada and China").

\section{REFERENCES}

[1] Levy, M., Computer-Assisted Language Learning: Context 
and Conceptualization, Oxford University Press, Oxford, March 1997.

[2] Chen, J.L., The Integration of Computer and Networks into Foreign Language Teaching ---- A Research Based on College English Teaching Reform, Shanghai International Studies University, Nov. 2010.

[3] Huang, F., "On the Development of Computer and New English Teaching Models," Computer-Assisted Foreign Language Education, Shanghai Foreign Language Audiovisual Publishing House, Shanghai, pp. 43-48, Oct. 2007.

[4] Yuan, W.W., and Wu, Q.L., "Reciprocal Teaching: An Integration of Situated Teaching and Cognitive Teaching," Journal of Psychological Science, the Chinese Psychological Society, Shanghai, pp. 438-441, March 2005.

[5] Sato, Manabu (Zhong, Qi-quan, trans.), Pleasure of Learning Toward Dialogic Practice, Education and Science Press, Beijing, 2004, (Original work published 1999 in Japanese).

[6] Mosston, M., and Ashworth, S., Teaching Physical Education (5th ed.), Benjamin Cummins, San Francisco, CA, 2002.

[7] Baxter Magolda, Marcia B., Creating Contexts for Learning and Self-authorship, Vanderbilt University Press, Nashville, TN, 1999.
[8] Brown, A.L., and Campione, J., "Designing a Community of Young Learners: Theoretical and Practical Lessons," How students learn: Reforming schools through learner-centered education, American Psychological Association, Washington, DC, pp. 153-186, 1998.

[9] Mitnik, R., Recabarren, M., Nussbaum, M., and Soto, A., "Collaborative Robotic Instruction: A Graph Teaching Experience," Computers \& Education 53(2), Elsevier, pp. 330-342, 2009.

[10] Chen, J.L., "A Study on Computer and Foreign Language Teaching Model", a paper submitted to the 7th Cross-Strait Conference on the Teaching of Foreign Languages, Taiwan, Oct. 2010.

[11] Yu, W.K., "Establishment of Individualized\& Autonomous Learning Center", Computer-Assisted Foreign Language Education, Shanghai Foreign Language Audiovisual Publishing House, Shanghai, pp. 71-74, Feb. 2006.

[12] McMillan, D. W., and Chavis, D. M., "Sense of community: A definition and theory", Journal of Community Psychology 14 (1), Wiley Periodicals Inc., San Francisco, pp.6-23, 1986.

[13] Stahl, G., and Hesse, F., "Practice perspectives in CSCL", International Journal of Computer Supported Collaborative Learning, 4(2), The International Society of the Learning Sciences, pp. 109-114, 2009. 